\title{
老化に関する栄養学的研究 (I)
}

\author{
Nutritional Study of Ageing (I)
}

\author{
鉄欠乏がネズミの血中 SH 化合物打よび胃表皮に及ぼす影響 \\ Effect of Iron Deficiency on Sulfhydryl Compounds of Blood and \\ Epithereal Structure of Stomach in Rats
}

（昭 和 43 年 9 月 25 日受 理）

\begin{abstract}
小柳 達 男* 湧 口泰 昌*
(Tatsuo Koyanagi) (Yasumasa Yuguchi)

北 浦 晧 三* 高 橋 伸 子*

(Kozo Kitaura) (Nobuko Takahashi)
\end{abstract}

Female rats of the Wistar strain were divided into 4 groups. Basal diets contained either 6 or $18 \%$ casein, and other constituents were soybean oil 6 , salts (excluding iron) 4, cellulose 2, vitamin mixture 1, $d l$-methionine $0.2(\%)$ and glucose to make up $100 \%$. The corresponding control diets differed only in their iron supplement. The 4 kinds of diet were fed to the 4 groups of rats.

In 74 days haemoglobin concentration of iron deficient rats fed on 6 or $18 \%$ casein diet dropped sharply and it reached to the values of 3.1 or $4.1 \mathrm{~g}$ per $100 \mathrm{ml}$ of blood respectively. Sulfhydryl compounds when determined by DTNB method showed that the deficient rats, both on 2 levels of protein had much lower values in their blood than animals fed on control diets. The results obtained in this study were in conflict with those of Ling et al. The erythrocyte of the deficient animals was seen more liable to hypotonic haemolysis than that of control animals. Microscopic examination of the gastric mucosa of the deficient animals showed a change in parietal cells showing a hypoactivity. The observation was not in accord with that of Valsberg et al. who observed no structural changes in stomach of iron deficient rat.

老化は動物体内の代謝の際に生ずる free radical（遊 離根, 対になっていないェレクトロン) のために起こる といわれている。この free radical はニコチン酸䤃素 やフラビン酵素による脱水索作用のような分子状酸素が 水に還元される時，あるい倣射線の照射によっても動 物体内に生ずることが認められている1)。この free radical を打消す主なるのは SH 化合物であり，血液中で は血球に集中しているグルタチオンが最す重要である。 したがって血液中にグルタチオン含量を高めておくこと は老化を防ぐために有効であると思われる。

従来栄養的欠陥により血中の SH 含量を減少させるす

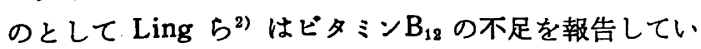
る。そうして彼らはビタミン $\mathrm{B}_{12}$ と異なり葉酸や鉄の不 足は血中 SH 含量に影響しないと述べている。グルタチ オンは Johnston ら゙: によれば肝葴内でグルタミン酸,

$*$ 果北大学農学部
システィン,グリシンおよび ATP で合成できるのであ って ATPはグルタチオンの合成に欠くことができな い。動物が鉄不足のときは酸素の供給が減り ATP の生 産も減るのであるから動物が鉄に不足した場合は当然グ ルタチオンの合成は低下するすのと予想される。そこで Ling らが，鉄欠乏でも血中 SH が減らないという事実 が果たしてその通りかどうかを確かめるためネズミの鉄 欠乏試験を行ない血中 $\mathrm{SH}$ の測定を行なった。 $\mathrm{SH}$ は血 球の膜の安定性に関係しているので低張圧液中での溶血 性について調べ, 胃壁の桡造についても組織学的観察を 行なった。ここにその大要を報告する。

$$
\text { 実験 }
$$

飼料および動物：基礎飼料は. $6 \%$ \%または $18 \%$ カでイン を含む低タンパク質と普通タンパク質の 2 種を用いた。 飼料中の他の成分はダイズ油 6 , 鉄を除いた塩類 4 ） 4 , 七 


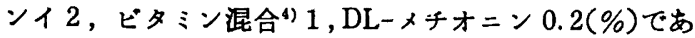
って残りはブドウ糖を配合した。そうして対照区には鉄 を除かない塩類を用いた。こうして作った 4 種の飼料を 4 群のネズミに与えた。試験動物は体重69g の Wistar 系雌ネズミ40頭で10頭ずつ 4 群に分けステンレス金網製 の飼育籠に 1 匹ずつ入れ飼料と水とを自由に与えた。

分析：飼育期間中，尾を傷つけて採血しへモグロビン をシアンへモグロビン法"), 血中 SH は DTNB $\left(5,5^{\prime}-\right.$ dithio bis 2-nitrobenzoic acid) 法尚で測定した。血球 の低張王溶血度は飼育試験の終りに Prankerd ${ }^{7}$ )の方法 を一部改めて行なった。すなわち $0.1 〜 0.2 \mathrm{ml}$ の血液を クエン酸ソーダ水溶液に緐濁させ， $0.9 \%$ 食塩水で 2 回 洗ったのち，この中から 1 定量を遠沈管にとり，種々浱 度の食塩水 $5 \mathrm{ml}$ を加え室温に24時間放置した。そこで 遠心分離後上澄についてへモグロビンを测定した。

組繳镜察：胃壁の腺部をフォルマリン固定後常法によ りヘマトキシリンおよびェオシンで染色した。

\section{結果}

発有：発育の経過は第 1 四に示したようでタンパク質 の量の多少により発育に差があるが，その各々について 鉄の無いときは発育が劣った。へモグロビンおよび血中 $\mathrm{SH}$ は第 1 表に示したごとく鉄欠乏の群は $6 \%$ 扰よび 18 \%カゼインの両タンパクレベルで低い値を示した。

血球の低張王溶血性 : 先ず老若ネズミの血球について 試験した。その成續は第 2 表のごとくで 3 カ月のものよ り28カ月の方が血球の脆弱性が增していることがわかっ た。次に鉄欠乏の場合を見ると第 3 表に示したごとく鉄 不足の場合に溶血しやすく，とくに低タンパク飼料の時 は一層溶血しやすかった。
第 1 图 各群のネズミの発育曲線

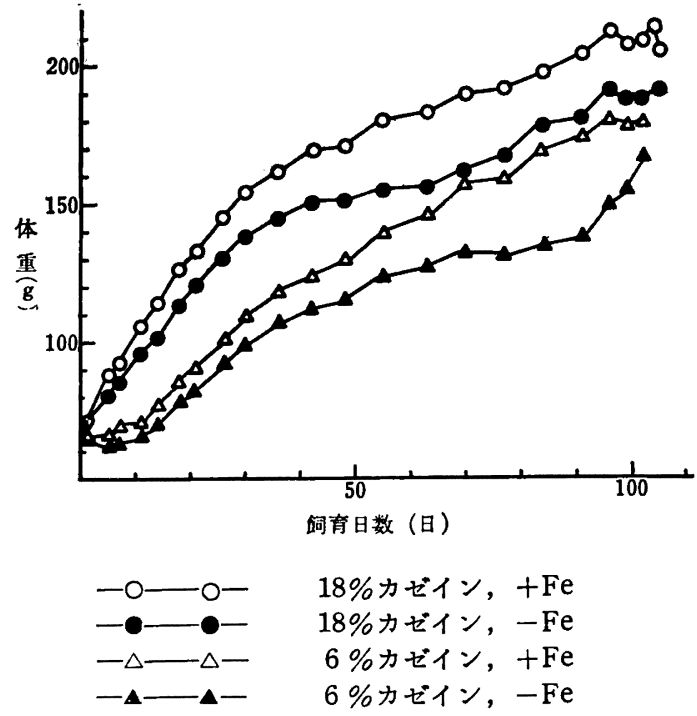

組織観察：顕徽鏡観察によると鉄欠乏のものは胃底部 の塩酸を分泌する紊細胞 (parietal cells) に変化が認め られた。6\%カゼイン飼料のものはタンパク質欠乏た けによっても醳素分泌細胞の核消失や空胞化が見られた が，鉄欠乏が組み合わさると障害はさらにひどかった。 18\%カゼイン飼料でも鉄欠乏の影響か認められた。す なわち，粘液を分泌する副細胞や醳素を分泌する主細胞 (chie fcells) の変化は著明でないが旁細胞では対照群 において核周囲の細胞質の透明化が增していて酸を分泌 した事を示するのが多く見られたのに対し（図2，白矢 印）鉄欠乏のものではこのような細胞はあまり見られな かった。（図 2 参照）

第1表 ヘモグロビン扣よび血中 SH 化合物含量

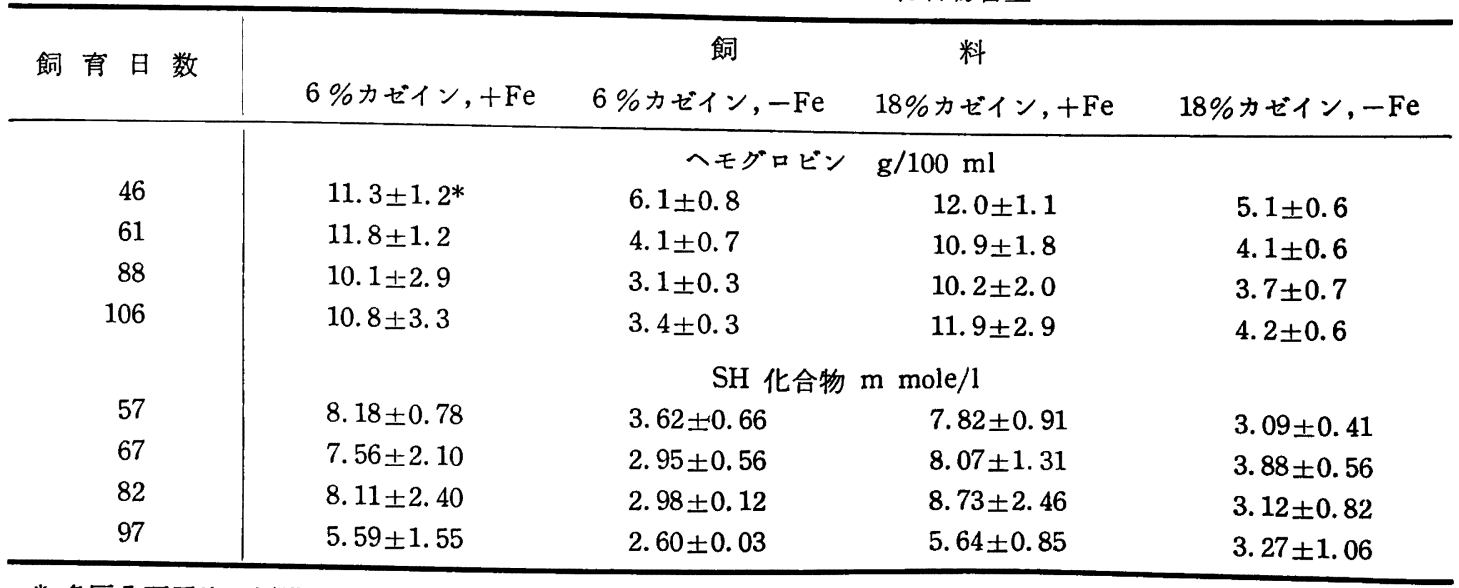

* 各区 5 頭平均士標準偏差 
第 2 表 赤血球の低張王溶血に及ほ十加令の影譬

\begin{tabular}{|c|c|c|c|c|c|}
\hline & \multicolumn{5}{|c|}{$\mathrm{NaCl}(\%)$} \\
\hline & 0.70 & 0.60 & 0.55 & 0.50 & 0.40 \\
\hline 若ネズミ( 3 カ月) (1) & $6.3^{(2)} \pm 2.0^{(3)}$ & $9.4 \pm 4.3$ & $20.3 \pm 7.0$ & $32.5 \pm 5.1$ & $66.0 \pm 9.0$ \\
\hline 老ネズミ(28カ月) & $7.0 \pm 2.1$ & $11.5 \pm 4.7$ & $28.8 \pm 11.0$ & $60.9 \pm 17.9$ & $94.6 \pm 8.9$ \\
\hline \multirow[t]{4}{*}{ (1) 老若とす市服固型飼料 } & \multicolumn{3}{|c|}{ （2）蒸畄水中での溶血を 100 とした場合の相対值 } & \multirow{2}{*}{\multicolumn{2}{|c|}{ (3) 5 頚平均土標準偏差 }} \\
\hline & \multicolumn{3}{|c|}{ 第 3 定 赤血球の低㖘王溶血に } & & \\
\hline & \multicolumn{5}{|c|}{$\mathrm{NaCl}(\%)$} \\
\hline & \multicolumn{2}{|c|}{0.55} & 0.50 & \multicolumn{2}{|c|}{0.40} \\
\hline $6 \%$ 6 ガイン, $+\mathrm{Fe}$ & \multicolumn{2}{|c|}{$9.0 \pm 1.5^{*}$} & $21.0 \pm 4.2$ & \multicolumn{2}{|c|}{$52.1 \pm 12.5$} \\
\hline $6 \%$ ガイン, $-\mathrm{Fe}$ & \multicolumn{2}{|c|}{$45.4 \pm 15.2$} & $65.0 \pm 6.9$ & \multicolumn{2}{|c|}{$82.8 \pm 9.3$} \\
\hline $18 \%$ ガイン $+\mathrm{Fe}$ & \multicolumn{2}{|c|}{$9.9 \pm 1.5$} & $17.9 \pm 3.8$ & \multicolumn{2}{|c|}{$45.0 \pm 12.9$} \\
\hline $18 \%$ ガイン,$-\mathrm{Fe}$ & \multicolumn{2}{|c|}{$26.4 \pm 8.5$} & $37.3 \pm 15.9$ & \multicolumn{2}{|c|}{$50.5 \pm 27.6$} \\
\hline
\end{tabular}

*第 2 表脚注 (2)(3) 参照

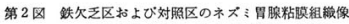
ヘマトキシリン・エオンン染色 $\times 400$ 上 : $18 \%$ ガイン, $+\mathrm{Fe}$ (対照区) 下: $18 \%$ ガイン, -Fe, 旁練胞の菜縮，乱れが見られる

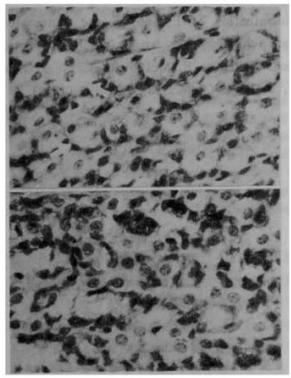

\section{考察}

Ling らは鉄欠乏でネズミの血中 SH が珹らないとい うが我々は $6 \%$ および18\%カゼイン飼料の両者て鉄欠之 により著明に SH が低下することを認めた。Ling らの 成䌙と一嘋しなかったことは説明できないが，SH の定
量法の違いにも関係むると思われる。

SH 化合物は free radical の打消し, 動物体内の醉素活

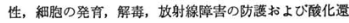
元にす重要であることは多くの研究で明らかである》。 るし倞の不足により血中のSH 化合物の娍少があるとす れは上上反応に悪影響を与え結局は動物の老化を促すの でないかと思われる。SH 化合物は膜の安定性にす関 㐿しているので，低張王液での赤血球の脆弱性が蛈不足 て增加したことは血中の SH の低下と関俰があると思わ れる。な祝老化ネズミの血球が若ネズミの血球より溶血 し易いことすこれに関速して興味がある。

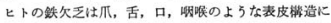
変化を生しることや，鉄不足で角血している患者方漫性 胃炎や無酸症を招くことは古くから知られている。この よ5に鉄の欠乏はヒトの胃にこのような垶害を起こさせ るにかかからず，轶欠そのネズ、の胃に及にす影算に関 する研究はわずかにValsberg らッのものがあるだけで

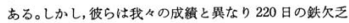
によってネズミの胃には何らの变化す生じなかったと報 告している。この成躦の不一致は蛈欠乏の程庭の善によ るものであろら。彼らは試験期間中, 血中へモグロビンは 血液 $100 \mathrm{ml}$ 中 $6 \sim 9 \mathrm{~g}$ であるのに対し, 我ヶのは 61 日 ですてに $4 \mathrm{~g}$ にまで低下していた。すなわち，彼らのネ ズミは鉄欠そが埾度のbのであったすのと思われる。

ヒトの場合菻縮性慢性胃焱で無酸症にまでなったるの は胃ガンの前駆症状といわれているが，鉄不足が胃粘谟 の酸分泌紐胞の機能低下を起こすとい.5本実験の成繥は

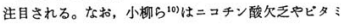


ンA 欠乏11)のネズミの胃においては酸分泌細胞の機能え 進を見た。栄養素の種類により胃腺に対するその欠乏の 影響が異なるのは興味がある。

要 約

鉄欠乏によりネズミの血中 SH 化合物が減少し赤血球 は脆弱性を增した。老ネズミの赤血球は若ネズミのより 脆弱である。鉄欠乏により胃腺の酸分泌細胞に变化が起 きた。

本研究は文部省科学研究費によって行なった。組織観 察に助力を与えられた星野忠彦氏, 山田正二氏に謝意を 表わす。
文献

1) Harman, D.: J. Gerontol. 15, 38 (1960)

2) Ling, C. T. \& Chow, B. F.: J. Biol. Chem., 202, 445 (1953)

3) Johnston, R. B. \& Bloch, K.: J. Biol. Chem., 188, 221 (1951)

4) Harper, A. E.: J. Nutr., 68, 405 (1959)

5) King, E. J.: Biochem. J., 41, XXXIII (1947)

6) Ellman, G. L.: Arch. Biochem. Biophys., 82, 70 (1959)

7) Prankerd, T. A. J.: J. Physiol., 143, 325(1958)

8) Barron, E.S. G.: Adv. Enzymol., 11, 201(1951)

9) Valsberg, L.S.: Brit. J. Nutr., 15, 473 (1961)

10）小柳達男, 山田正二:ビタミン, 36, 126(1967)

11）山田正二, 小柳達男 : (未発表)

\section{アミノ酸自動分析計によるリシシン迅速定量法}

穀類のリジン含量だけを迅速かつ正確に定量する方法 を考案した。アミノ酸自動分析計のショートカラムに試 料 3 点を連続して吸着させ, 3 個のリジンピークを 1 グ ループとして溶出, 記録する。リジンか溶出したら 0.2 N水酸化ナトリウム, ついでクエン酸緩衝液を流してカ ラムを再生し，つぎの分析を行なう。条件はクェン酸緩 衝液 $\mathrm{pH} 5.10, \mathrm{Na}$-濃度 $0.20 \mathrm{~N}$, カラム温度 $40^{\circ} \mathrm{C}$, 樹 脂はペックマン PA-35, カラム中の樹脂の長さ $9 \mathrm{~cm}$,
流速 $68 \mathrm{ml} / \mathrm{hr}$ である。この条件で朝 8 時から夕 5 時ま でにカラム 1 本で15点, 3 本で36点のリジンの定量が可 能である。精度は96〜99\%でかなりよい。

Determination of Lysine on the Automated Amino Acid Analyzer by a Triplicate-Sample Method. Villegas, E., McDonald, C.E. \& Gilles, K. A., : Cereal Chem., 45, 432 436 (1968)

(检持) 